\title{
Morphophysiological Responses of Wheat Cultivars in Competition With Diploid and Tetraploid Ryegrass
}

\author{
Renata Baldessarini \\ Laboratory of Sustainable Management of Agricultural Systems, Federal University of \\ Fronteira Sul, Erechim Campus \\ RS 135 - km 72, no 200, 99.700-000, Erechim, RS, Brazil \\ E-mail: baldessarini.renata@gmail.com \\ Leandro Galon (Corresponding author) \\ Laboratory of Sustainable Management of Agricultural Systems, Federal University of \\ Fronteira Sul, Erechim Campus \\ RS 135 - km 72, no 200, 99.700-000, Erechim, RS, Brazil \\ E-mail: leandro.galon@uffs.edu.br \\ Tel.: +5554996985955 \\ Leandro Vargas \\ Brazilian Agricultural Research Corporation \\ BR 285, km 174, 99.001-970, - Passo Fundo, RS, Brazil \\ E-mail: leandro.vargas@embrapa.br
}

\section{Caroline Müller}

Laboratory of Sustainable Management of Agricultural Systems, Federal University of Fronteira Sul, Erechim Campus

RS 135 - km 72, no 200, 99.700-000, Erechim, RS, Brazil

E-mail: carolinemulleram@gmail.com

\section{Daiani Brandler}

Laboratory of Sustainable Management of Agricultural Systems, Federal University of 
Fronteira Sul, Erechim Campus

RS 135 - km 72, no 200, 99.700-000, Erechim, RS, Brazil

E-mail: daianibrandler@hotmail.com

Jessica Dias Gomes da Silva

Laboratory of Sustainable Management of Agricultural Systems, Federal University of

Fronteira Sul, Erechim Campus

RS 135 - km 72, no 200, 99.700-000, Erechim, RS, Brazil

E-mail: jessicadiasgomes@hotmail.com

Cesar Tiago Forte

Department of Agronomy, Federal University of Santa Maria

Av Roraima, n 1000, 97.105-900, Santa Maria, RS, Brazil

E-mail: cesartiagoforte@ hotmail.com

Milena Barretta Franceschetti

Laboratory of Sustainable Management of Agricultural Systems, Federal University of Fronteira Sul, Erechim Campus

RS 135 - km 72, no 200, 99.700-000, Erechim, RS, Brazil

E-mail: milena.barretta@hotmail.com

Siumar Pedro Tironi

Laboratory of Seeds and Grains, Federal University of Fronteira Sul, Chapecó Campus SC 484 - km 02, 89.815-899, Chapecó, SC, Brazil.

E-mail: siumar.tironi@gmail.com

Gismael Francisco Perin

Laboratory of Sustainable Management of Agricultural Systems, Federal University of Fronteira Sul, Erechim Campus

RS 135 - km 72, n. 200, 99.700-000, Erechim, RS, Brazil 
E-mail: gismaelperin@gmail.com

Received: Mar. 31, 2020

doi:10.5296/jas.v8i3.16779
Accepted: Apr. 21, 2020

Published: Apr. 27, 2020

URL: https://doi.org/10.5296/jas.v8i3.16779

\begin{abstract}
Wheat crop growth and development can be affected by weed infestation, especially ryegrass. Thus, the objective of this study was to evaluate the competitive ability of wheat cultivars with the diploid and tetraploid ryegrass biotypes. Greenhouse experiments were conducted in a completely randomized design with four replications. BRS Parrudo and TBIO Sinuelo wheat cultivars and the competitors ryegrass diploid and tetraploid were used. The population of each species was defined and then the replacement series experiments were carried out, containing the following proportions of wheat and ryegrass plants: 100:0, 75:25, 50:50, 25:75; and $0: 100 \%$, equivalent to $32: 0 ; 24: 8 ; 16: 16 ; 8: 24$; and $0: 32$ plants per pot. Fifty days after species emergence, physiological traits, such as photosynthetic activity $(A)$, stomatal conductance $\left(g_{\mathrm{S}}\right)$, transpiration rate $(E)$, internal concentration of mesophyll $\mathrm{CO}_{2}\left(\mathrm{C}_{\mathrm{i}}\right)$, water use efficiency (WUE), and carboxylation efficiency (CE), were evaluated, along with the morphological traits of leaf area (LA), stem diameter (SD), number of tillers (NT), and shoot dry mass (DM). Competitiveness analysis was performed by means of diagrams applied to substitutive experiments using relative competitiveness indices. The ryegrass, both diploid and tetraploid, had a negative effect on the variables related to $A$, WUE and also those associated with plant growth. The ryegrass negatively changed the LA, DM, SD, and NT of the cultivars BRS Parrudo and TBIO Sinuelo, which demonstrates competition between the cultivars of wheat and the weed ryegrass with mutual damage to the species involved in the community. Interspecific competition caused greater damage to species development when compared to intraspecific competition. Therefore, ryegrass control, even at low density, is recommended for wheat cultivation.
\end{abstract}

Keywords: Triticum aestivum, Lolium multiflorum, Competitive interaction

\title{
1. Introduction
}

Wheat is of great importance for human consumption, as it is one of the three most cultivated cereals in the world, along with corn and rice (FAO, 2020). Despite its genetic improvement and great edaphoclimatic adaptability (Szareski et al., 2019), reductions in the productivity of this crop occur, in large part, by weed interference. This is due to incorrect management and the resistance acquired by weeds.

Competitiveness with weeds affects productivity and the quality of raw materials destined for industry, resulting in economic losses for agricultural producers (Gherekhloo et al., 2010; Galon et al., 2019). Among the weeds infesting wheat, ryegrass (Lolium multiflorum) and turnip (Raphanus raphanistrum and $R$. sativus) stand out as those that cause the greatest 
competition for environmental resources, such as water, light, and nutrients, and those that cause higher reductions in crop production (Tironi et al., 2014; Agostinetto et al., 2017; Galon et al., 2019).

Ryegrass is a rustic and vigorous species that is considered naturalized in several regions. It has good tillering, and, under adequate nutritional conditions, it can surpass other winter forages. It also has good palatability to ruminants and tolerance to trampling (Fontaneli et al., 2012; Stivanin et al., 2014). Despite being a winter forage indicated for the southern region of Brazil, it becomes a very aggressive weed and is difficult to control when it infests the wheat crop. In addition, biotypes resistant to EPSPs, ALS, and ACCase inhibiting, which represent the main classes used for the chemical control of these weeds, have been reported (Kaundun et al., 2013; Agostinetto \& Vargas, 2014; Mariani et al., 2015; Mahmood et al., 2016; Henckes et al., 2019).

In its natural form, ryegrass (annual or perennial) is found in diploid form $(2 n=2 x=14$ chromosomes). However, it is possible to obtain tetraploid plants ( $2 \mathrm{n}=4 \mathrm{x}=28$ chromosomes) by employing the chromosomal duplication technique using alkaloids through genetic breeding (Pereira et al., 2014; Pereira et al., 2017). The crossing of diploid (2n resistant) and tetraploid (4n susceptible) individuals could be a solution for the dilution of resistance by generating viable triple (3n) individuals, but they are usually sterile due to the presence of unpaired chromosomes in meiosis (Bustamante et al., 2015).

Doubling the number of chromosomes directly affects plant performance, such as increased cell volume and levels of soluble carbohydrates, proteins, and lipids, which allow greater digestibility, ruminal efficiency, and animal performance (Smith et al., 2003; Nair, 2004; Balocchi \& López, 2009; Costa et al., 2018). In addition to an increased life cycle, improvements have been reported in the quality and forage mass, resistance to diseases and abiotic stresses, and uniformity and stability of populations (Pereira et al., 2012; Confortin, 2013).

Competition between weeds and crops has been considered the main biotic cause that generates losses in grain productivity and quality (Délye et al., 2013; Hussain et al., 2017). Competition between plants can occur between individuals of the same or different species, which is known as intraspecific or interspecific competition, respectively. The damage caused to growth, development, and productivity is conditioned by the duration of competition between competing plants (Côrrea et al., 2015). In general, the degree of interspecific competition depends on factors related to the weed community specific composition, density, and distribution and the crop itself cultivar, row spacing, sowing density, and adopted management (Vian et al., 2016; Galon et al., 2019).

To determine the competitive interactions between species in the community, the studies that stand out are those in which the density of cultivated plants is generally constant but the density of weeds varies according to the soil seed bank and the environmental conditions that change the level of infestation (Agostinetto et al., 2010; Galon et al., 2011; Galon et al., 2015; Forte et al., 2018). Thus, it is important to verify the influence of variation between species in the proportion of plants since weed density is the factor that most affects the growth and development of crops. 
In this sense, substitution series experiments make it possible to assess interspecific and intraspecific competition, allowing an understanding of the population effect and the proportion between crops and weeds, thereby generating more complete information about the competitive process between plants. The substitution series includes the cultivation of the crop alone and/or in a mixture with weeds in varying proportions between species while keeping the total population of plants constant (Aminpanah \& Javadi, 2011). The work had as its hypotheses: i) the coexistence of wheat plants with ryegrass results in losses in the wheat physiological and growth traits; and ii) diploid ryegrass has less competitive potential than tetraploid ryegrass. Thus, the work aimed to evaluate the competitive ability of wheat cultivars when living with two ryegrass biotypes.

\section{Material and Methods}

\subsection{Cultivation Conditions and Experimental Design}

The experiment was conducted in a greenhouse at the Federal University of Fronteira Sul (UFFS), Erechim campus. The wheat seeds, BRS Parrudo and TBIO Sinuelo cultivars, and ryegrass, diploid and tetraploid biotypes, were sown in polyethylene pots with a capacity of 8 $\mathrm{L}$, filled with soil from a crop characterized as humic aluminoferric red latosol (EMBRAPA, 2013). The correction and fertilization of the soil was carried out based on a physical-chemical analysis following the technical recommendations for the cultivation of wheat (ROLAS, 2016). For all experiments, a completely randomized design with four replications was used.

\subsection{Determination of the Population by Monocultures}

Preliminary experiments were carried out in a series of additives in monoculture for wheat cultivars and ryegrass biotypes in order to determine the density of plants necessary for the constant final production of leaf area (LA) and shoot dry mass (DM). Plant densities of 1, 2, 4, $8,16,24,32,40,48,56$, and 64 plants per pot, equivalent to $25,49,98,196,392,587,784$, $980,1,176,1,372$, and 1,568 plants $\mathrm{m}^{-2}$, were evaluated. At 50 days after the emergence, LA was measured using a portable leaf area meter (CI-203, BioScence, USA) and the DM was obtained after drying the material in an oven with forced air circulation, temperature of $60 \pm$ $5^{\circ} \mathrm{C}$, until the mass reached constant weight. These values were used to obtain a constant production of LA and DM with the density of 32 plants pot $^{-1}$ for the two wheat cultivars as well as for the diploid and tetraploid ryegrass biotypes, which represents 784 plants $\mathrm{m}^{-2}$ in total (data not shown).

\subsection{Competitiveness Assessment}

From the initial experiments, four other experiments were conducted to assess the competitiveness of the two wheat cultivars with the two ryegrass biotypes. The experiments were carried out in a series of substitutions using different combinations of cultivars and weeds and varying the relative proportions of plants in the pots $(32: 0 ; 24: 8 ; 16: 16 ; 8: 24$; and

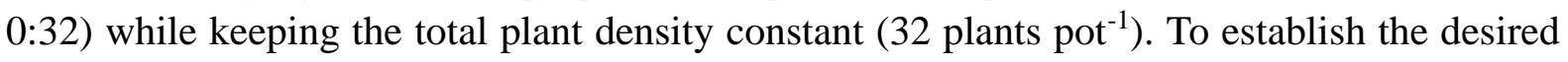
densities in each treatment and to obtain uniformity of the seedlings, the seeds were originally sown in trays and later transplanted to the pots. 


\subsection{Physiological Traits}

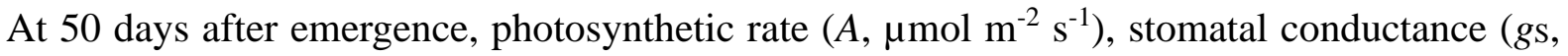
mol m $\mathrm{m}^{-2} \mathrm{~s}^{-1}$, transpiration $\left(E\right.$, mol $\left.\mathrm{H}_{2} \mathrm{O} \mathrm{m}^{-2} \mathrm{~s}^{-1}\right)$, and internal $\mathrm{CO}_{2}$ concentration $\left(\mathrm{C}_{\mathrm{i}}, \mu \mathrm{mol}\right.$ $\mathrm{mol}^{-1}$ ) were measured. From the ratio between $A / \mathrm{C}_{\mathrm{i}}$ and $A / E$, it was possible to calculate the instantaneous carboxylation efficiency $\left(\mathrm{CE}, \mathrm{mol} \mathrm{CO}_{2} \mathrm{~m}^{-2} \mathrm{~s}^{-1}\right)$ and the water use efficiency (WUE, mol $\mathrm{CO}_{2} \mathrm{~mol} \mathrm{H}_{2} \mathrm{O}^{-1}$ ), respectively. The physiological measurements were performed in the middle third of the first fully expanded leaf using the infrared gas analyzer (IRGA, LCA PRO, Analytical Development Co. Ltd, Hoddesdon, UK). One block was evaluated per day between 8:00 and 10:00 a.m. under radiance ( 1,100 PAR), temperature $\left(15-20{ }^{\circ} \mathrm{C}\right)$, and relative humidity (60-70\%) environments.

\subsection{Morphological Traits}

The stem diameter $(\mathrm{SD}, \mathrm{mm})$, leaf area $\left(\mathrm{LA}, \mathrm{cm}^{2} \mathrm{~m}^{-2}\right)$, and shoot dry mass (DM, g) were evaluated at 50 days after emergence. The SD was randomly evaluated for 10 plants of each experimental unit. LA and DM were determined as described in item 2.2 and the number of tillers (NT) was evaluated.

\subsection{Relative Productivity and Competitiveness Indices}

The analysis of the relative productivity or conventional method for substitute experiments was carried out from the diagram construction based on the relative productivity (RP) and total relative productivity (TRP), as described by Cousens (1991), Roush et al. (1989) and Bianchi et al. (2006). From the graphical analysis, it is possible to characterize the species with equivalent ability (RP represented by a straight line) and check if there is a loss (concave line) or benefit (convex line) in the growth of one or both species. From the TRP data, it is possible to observe competition for the same resources (TRP $=1$, straight line), avoided competition (TRP > 1, convex line), or mutual impairment to growth (TRP < 1, concave line) (Cousens, 1991).

To obtain the relative competitiveness index ( $\mathrm{RC} ; \mathrm{RC}=\mathrm{PRx} / \mathrm{PRy})$, relative grouping coefficient (K; Kx = PRx/(1-PRx); Ky = PRy/(1-PRy)), and aggressiveness (AG; AG = PRx PRy) of the species, the 50:50 proportions (wheat and/or ryegrass) used in the experiments were calculated according to Cousens and O'Neill (1993). The RC represents the comparative growth of the BRS Parrudo and TBIO Sinuelo wheat cultivars in relation to both competitors diploid or tetraploid ryegrass. $\mathrm{K}$ indicates the relative dominance of one species over the other. AG indicates the most aggressive species. Therefore, BRS Parrudo and TBIO Sinuelo wheat cultivars will be more competitive than diploid and/or tetraploid ryegrass when RC> 1 , $\mathrm{Kx}>\mathrm{Ky}$, and $\mathrm{AG}>0$; on the other hand, ryegrass biotypes will be more competitive than wheat cultivars when $\mathrm{RC}<1, \mathrm{Kx}<\mathrm{Ky}$, and AG $<0$ (Hoffman \& Buhler, 2002).

\subsection{Statistical Analysis}

For the statistical analysis, the productivity or relative variation data was used to calculate the difference for the values of RP (DRP), obtained in the proportions 25, 50, and 75\%, in 
relation to the values belonging to the hypothetical line in the respective proportions $(0.25$; 0.50, and 0.75 for RP) (Bianchi et al., 2006).

The "T" test was used to evaluate the differences related to the DRP, TRP, RC, K, and AG indices (Roush et al., 1989; Hoffman \& Buhler, 2002). It was considered as a null hypothesis to test the differences of DRP and AG when the means are equal to zero $(\mathrm{Ho}=0)$; for TRP and $\mathrm{CR}$, when the averages are equal to one $(\mathrm{Ho}=1)$; and for $\mathrm{K}$, if the averages of the differences between $\mathrm{Kx}$ and $\mathrm{Ky}$ are equal to zero $[\mathrm{Ho}=(\mathrm{Kx}-\mathrm{Ky})=0]$. Likewise, for the $\mathrm{CR}$, $\mathrm{K}$, and $\mathrm{AG}$ indices, differences in competitiveness were considered when there was a significant difference by the " $\mathrm{T}$ " test in at least two of them.

The other results obtained were expressed in average values per treatment and submitted to analysis of variance by the $\mathrm{F}$ test, followed by the Dunnett average test, considering monocultures as controls in these comparisons. In all statistical analyzes, the significance level of $p \leq 0.05$ was adopted. The graphs were plotted using the ExpDes, Hmisc, multcomp and Cairo packages as described by Concenço and Galon (2014). All statistical analyzes and graphics were performed using the R program (v.3.5.3).

\section{Results and Discussion}

\subsection{Relative Productivities}

\subsubsection{Photosynthesis-Related Traits}

The relative productivity showed high reliability for the variables associated with photosynthesis, mainly $A$ and $\mathrm{C}_{\mathrm{i}}$, with variation for RPx and TRP between wheat cultivars TBIO Sinuelo and BRS Parrudo when competing with tetraploid or diploid ryegrass. High stability with a narrow confidence interval was observed between RP and transpiration rate $(E)$. The other variables, stomatal conductance $\left(\mathrm{g}_{S}\right)$ and water use efficiency (WUE), were considered only occasionally when there was visible stability from one of the competitors.

The RP for $A$ showed stability and higher photosynthetic rates of the crop due to the increase of its proportion in mixtures with weed. It was observed in the cultivar TBIO Sinuelo when competing with tetraploid ryegrass and in the cultivar BRS Parrudo when competing with the two biotypes of ryegrass. TBIO Sinuelo wheat cultivar in the presence of diploid ryegrass with a proportion of up to 50:50 showed lower RP and $A$ (Figure 1). However, the competitors showed differential behaviors in which tetraploid ryegrass reduced the $A$ below the expected hypothetical line in the presence of low proportions (100:0 and 75:25) in coexistence with the cultivars TBIO Sinuelo and BRS Parrudo. Diploid ryegrass showed an increase in $A$ for both wheat cultivars up to the proportion of 50:50 (Figure 1) and a decrease from this proportion in the association of plants.

For the TRP, which represent the behavior of the mixed crop and weed population in their different proportions, it was evident that there was damage to the mixed population (TRP) in the cultivar TBIO Sinuelo, mainly due to the reductions in $A$ in the crop due to the presence of ryegrass diploid (Figure 1) that was not observed in the wheat cultivar BRS Parrudo. BRS Parrudo was able to minimize the impact caused by diploid and tetraploid ryegrass on its 
photosynthetic metabolism, probably by maintaining the interception of light by lesser loss of leaf area. The competition for light between the plants of a community starts very early, affecting apical dominance (Almeida \& Mundstock, 2001). According to Ballaré et al. (1987), in communities formed by Poaceae with similar morphological characteristics, there is a reduction in tillering before mutual shading between plants occurs. The authors proposed that the quality of light incident on plants, such as extreme red radiation reflected by leaves, can act as an early indicator of competition. It is implicit that species that develop simultaneously and more quickly in height and leaf area compete more efficiently for light (Walker et al., 1988).

In addition, Ferreira et al. (2008), in studying the competitive potential of ryegrass biotypes on a wheat crop, observed that the glyphosate-resistant ryegrass had less of a negative effect on the crop than susceptible ryegrass, as was observed in the present study in which the effect of diploid ryegrass had the greatest negative effect on the wheat cultivar TBIO Sinuelo. Oliveira et al. (2014) also observed that the resistance of Lolium rigidum to glyphosate is accompanied by a reduction in the competitive capacity of this biotic when compared to the susceptible. In this sense, it is highlighted that the differences in competitiveness between the ryegrass biotypes may be related to changes or differentiation of biological characteristics affected by environmental factors, anthropic interference, or xenobiotic agents (Vargas et al., 2005).

The reduction in $A$ observed in tetraploid ryegrass plants up to the ratio of 50:50 and diploid ryegrass from the 50:50 proportion associated with TBIO Sinuelo wheat was accompanied by the increase in $\mathrm{C}_{\mathrm{i}}$, which indicates the occurrence of non-stomatal limitation (Figure 1). For the other comparisons, both for crops and weeds, showed a reduction in $\mathrm{C}_{\mathrm{i}}$ values with the increase in $A$, since $\mathrm{CO}_{2}$ is consumed by the photosynthetic process (Gest, 2002; Taiz et al., 2014). The carboxylation efficiency (EC) was proportional to A. High EC indicates high NADPH and ATP consumption rate and ribulose 1,5-bisphosphate regeneration rate, supplying $\mathrm{CO}_{2}$ to the carboxylation sites via stomata (Baker \& Rosenqvst, 2004). Both the cultivar BRS Parrudo and TBIO Sinuelo were able to keep the EC close to the expected values, regardless of their proportion in the mix with the competitor, but only BRS Parrudo was able to simultaneously maintain its EC and reduce the competitor's EC, indicating likely competition for the same resources demanded by the competing biotype. 


\section{Macrothink}

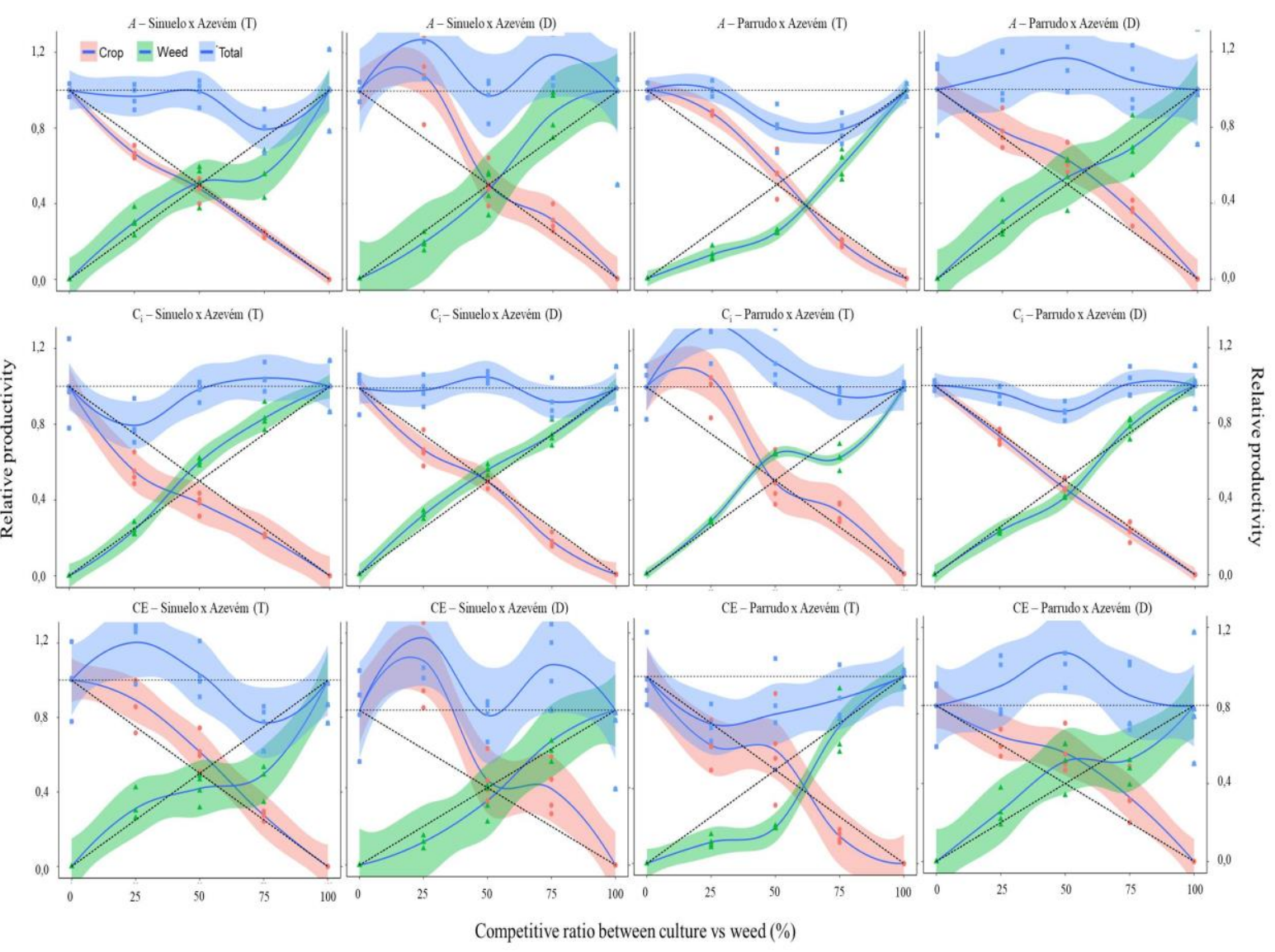

Figure 1. Photosynthetic rate $\left(A, \mu \mathrm{mol} \mathrm{m}{ }^{-2} \mathrm{~s}^{-1}\right)$, internal $\mathrm{CO}_{2}$ concentration $\left(\mathrm{C}_{\mathrm{i}}, \mu \mathrm{mol} \mathrm{mol}{ }^{-1}\right)$ and carboxylation efficiency $\left(\mathrm{CE}, \mathrm{mol} \mathrm{CO} 2 \mathrm{~m}^{-2} \mathrm{~s}^{-1}\right.$ ) of wheat plants cultivars TBIO Sinuelo or BRS Parrudo (•), in competition with the tetraplois (T) or diploid (D) ( $\boldsymbol{\Delta}$ ) ryegrass and total relative productivity (TRP) of the community ( $\square$ ), depending on the plants proportion.

Colored areas represent the confidence interval of the data at $5 \%$ probability

The RPs and TRPs of the $E$, WUE, and $\mathrm{g}_{s}$ of wheat were not consistent between the cultivars TBIO Sinuelo and BRS Parrudo, with levels of changes that mischaracterize the simple competitive and cultivar effect (Figure 2). It was observed that greater $\mathrm{g}_{S}$ allow a higher $E$ and, consequently, a proportional reduction in WUE (Figure 2). Water is a limiting resource for agricultural crops and, thus, lower water availability reduces the biomass of wheat plants in competition (Wanic et al., 2013). In this work, the variables linked to the water dynamics at the soil-plant-atmosphere interface demonstrate that competition for water was not a determining factor in the yield values of the cultivars and conditions evaluated.

\subsubsection{Growth-Related Traits}

Regarding the variables related to growth, narrow confidence intervals were observed for leaf area (LA), stem diameter (SD), number of tillers (NT), and shoot dry mass (DM) (Figure 3).

For LA, graphs with convex lines were obtained; that is, the deviations from the observed values were greater than those estimated (Figure 3) with, in this case, a benefit for crop growth. The higher relative growth of wheat in relation to weed may be related to the 
population of plants that competed with the crop. This occurs since weeds have greater competitive ability when in high population densities and not individually (Carvalho \& Christoffoleti, 2008; Agostinetto et al., 2013). Galon et al. (2011), when combining barley and ryegrass cultivars, obtained a graph with a convex line for the Hordeum vulgare cultivar MN 610 (in the proportion 25:75). Similarly, Forte et al. (2017) observed that the Glycine max crop competing with common blackjack and/or wild poinsettia showed greater relative growth for the variable LA. Still, the reduction in LA provided by competition (in the proportion of 25:75; Figure 3), or even by the genetic characteristics of wheat cultivars, may have caused the decrease in $A$, since these variables are directly linked to the absorption of light by photosynthetic pigments (Ballaré et al., 1987).

The stem diameter (SD) of the species involved in the competition showed little difference between the observed RP values (solid lines with confidence interval) and those that would be expected (straight dotted lines) (Figure 3). In the same way, the TRPs of the species were little affected; that is, they competed for similar resources in the environment, staying the same with values very close to the expected 1, except for the cultivar BRS Parrudo when in competition with tetraploid ryegrass.

It was observed for the number of tillers (NT) that they had concave lines when the wheat cultivars competed with diploid ryegrass, up to the proportion of 50:50 (16:16 pot ${ }^{-1}$ plants; Figure 3). This demonstrates that there was mutual damage between the species (cultivar and competitor), as previously observed in experiments with barley and ryegrass (Galon et al., 2011). 


\section{Macrothink}

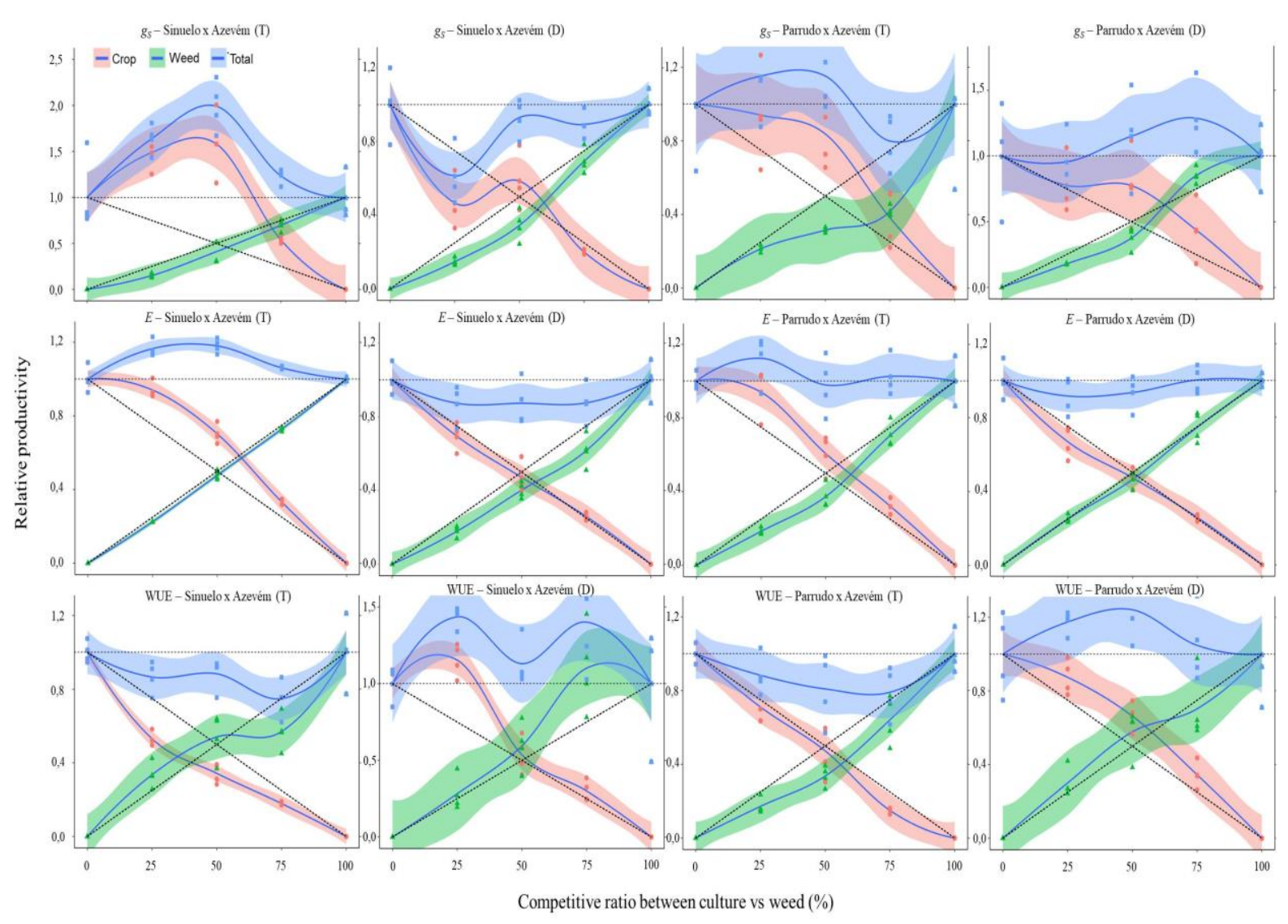

Figure 2. Stomatal conductance $\left(g \mathrm{~s}, \mathrm{~mol} \mathrm{~m}^{-2} \mathrm{~s}^{-1}\right)$, transpiration $\left(E, \mathrm{~mol} \mathrm{H}_{2} \mathrm{O} \mathrm{m}^{-2} \mathrm{~s}^{-1}\right)$ and water use efficiency (WUE, mol $\mathrm{CO}_{2} \mathrm{~mol} \mathrm{H}_{2} \mathrm{O}^{-1}$ ) of wheat plants cultivars TBIO Sinuelo or BRS

Parrudo $(\bullet)$, in competition with the tetraploids (T) or diploid (D) ( $\mathbf{\Delta}$ ) ryegrass and total relative productivity (TRP) of the community ( $\mathbf{\square})$, depending on the plants proportion. Colored areas represent the confidence interval of the data at $5 \%$ probability

DM showed high reliability and was reduced by competition for both diploid and tetraploid ryegrass, as well as wheat cultivars, with a decrease of up to 50\% in TRP (Figure 3). In general, regardless of the wheat cultivar, the crop tended to be more affected than the weed in the competition, with greater differences between the observed RP values (solid lines with confidence interval) and those that would be expected (dotted straight lines). The reduction in weed DM is expected and often depends on the intrinsic characteristics of the competing cultivar (Lamego et al., 2013). Therefore, we can see the high competitiveness imposed by ryegrass, both diploid and tetraploid, on wheat.

Competing with ryegrass, previous studies have reported a reduction in dry barley mass even in low competitor populations, especially when there is a lower water supply and with greater intensity at the end of the cycle (Galon et al., 2011; Wanic et al., 2013).

In this experiment model, LA together with DM have been described as the main variables affected for the wheat crop in competition with ryegrass and turnip (Rigoli et al., 2008), barley with ryegrass (Galon et al., 2011) and turnip (Galon et al., 2017), and soybeans in the presence of common blackjack and wild poinsettia (Forte et al., 2017). 


\subsection{Competitiveness Indices}

\subsubsection{Photosynthesis-Related Traits}

The CR, K, and AG indices indicate which species are most competitive and their joint interpretation determines with greater certainty the species' competitiveness (Cousens, 1991).

In all proportions, the $A$ of the cultivars TBIO Sinuelo and BRS Parrudo did not differ from their competition-free controls, as tested by the Dunnett test (Table 1). However, the cultivar BRS Parrudo showed a different effect and greater $\mathrm{RC}, \mathrm{Kx}$, and $\mathrm{AG}$ in relation to the tetraploid ryegrass competitor (Table 2). It is evident that, although they do not benefit from competition, they are also not affected until the level of occurrence of diploid or tetraploid ryegrass is equivalent to that of plants for this variable. Thus, it can be seen that BRS Parrudo has an advantage over tetraploid ryegrass. The diploid ryegrass and tetraploid competitors also showed similar $A$ to the competition-free control, except for tetraploid ryegrass in the presence of the BRS Parrudo cultivar (Table 2).

The EC showed that the behavior of the cultivars BRS Parrudo and TBIO Sinuelo at levels equal to those of the competitor (50:50) was not affected by the presence of the weed (Table 2). However, in equal proportions of competition, the $\mathrm{Kx}$ was higher than the Ky, showing an advantage to the crop. This occurred as the $A$ values increased significantly when the crop competed with tetraploid ryegrass (Table 3 ).

Respective relative competitiveness (CR) indicated that the cultivar BRS Parrudo had an advantage in competitive ability with the diploid and tetraploid ryegrass, while the RC for the TBIO Sinuelo cultivar did not show any significant effect; that is, the diploid or tetraploid ryegrass did not cause damage in relation to this cultivar for photosynthetic activity. This may have occurred due to the higher LA verified in the cultivar BRS Parrudo in relation to the cultivar TBIO Sinuelo, which may have provided greater competitive advantage for $A$. 


\section{Macrothink Institute ${ }^{\mathrm{TM}}$}
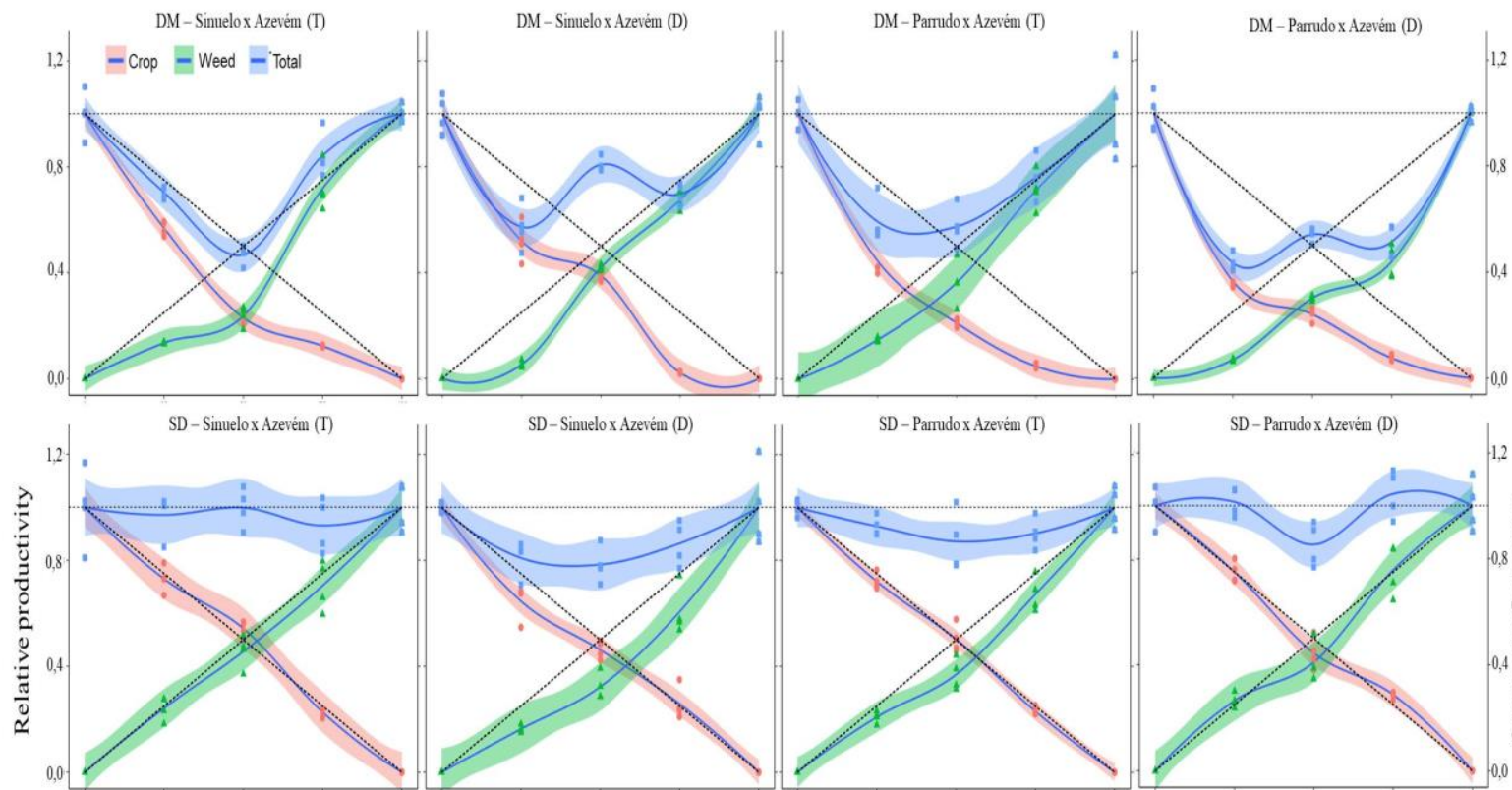

SD-Sinuelo x Azevém (D)

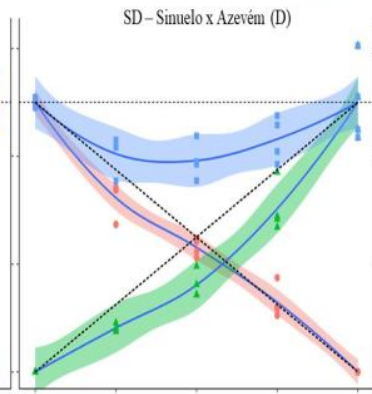

SD-Parndox Azevém (T)

SD-Parrudo x Azevém (D)
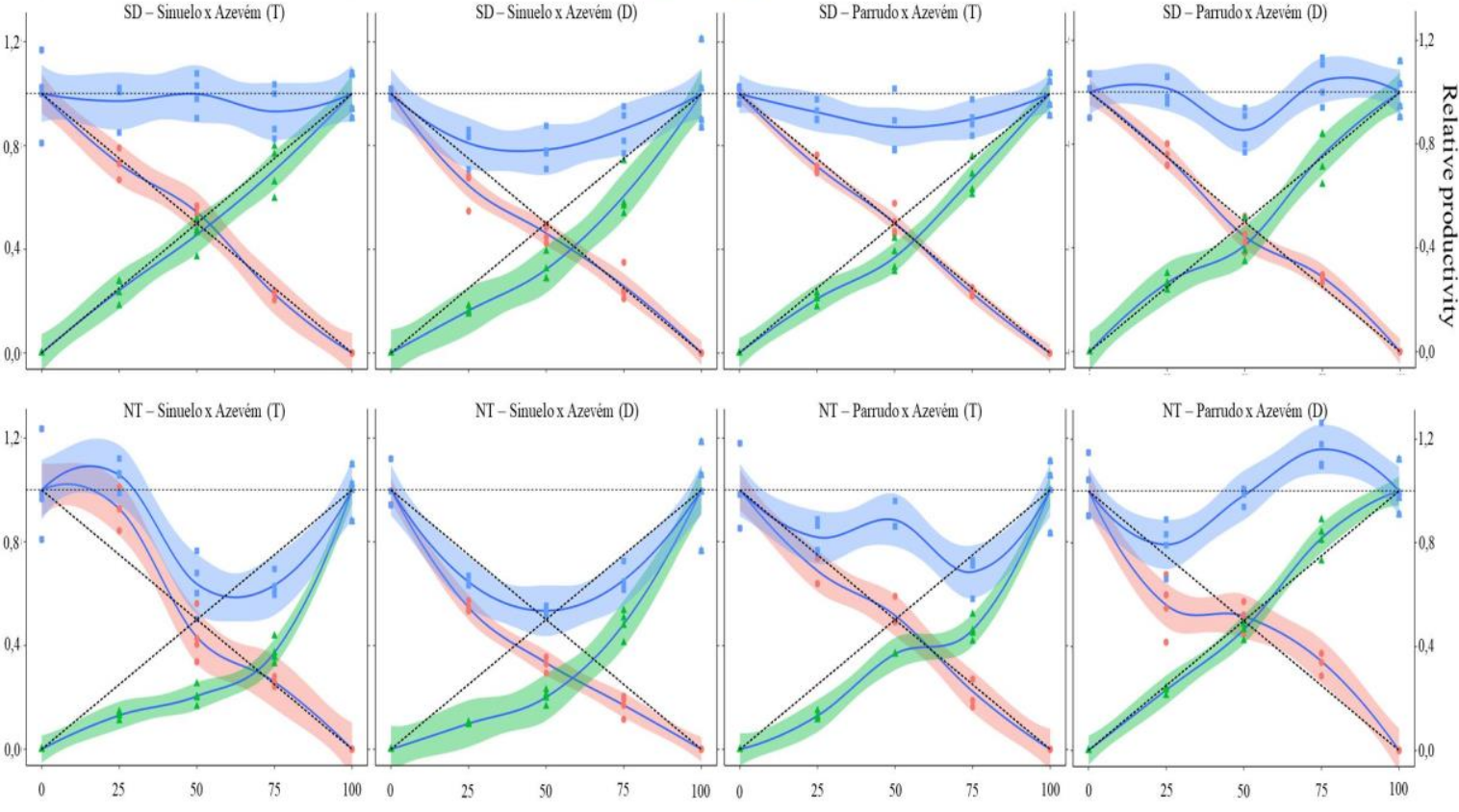

NT - Parndox Azevém (D)

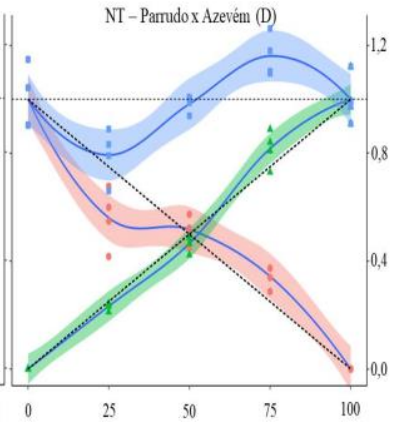

Competitive ratio between culture vs weed $(\%)$

Figure 3. Leaf area (LA, $\mathrm{cm}^{2} \mathrm{~m}^{-2}$ ), dry mass (DM, g), stem diameter (SD, mm) and number of tillers (NT) of wheat plants cultivars TBIO Sinuelo or BRS Parrudo $(\bullet)$, in competition with the tetraploids $(\mathrm{T})$ or diploid $(\mathrm{D})(\mathbf{\Delta})$ ryegrass and total relative productivity (TRP) of the community ( $\mathbf{\square})$, depending on the plants proportion. Colored areas represent the confidence interval of the data at $5 \%$ probability

The $E$ differed from the respective single control in all tested proportions, according to the Dunnett test $(\mathrm{p}<0.05)$ (Table 2), for both the crop and the weed when the cultivar BRS TBIO Sinuelo competed with tetraploid ryegrass. The RC, $\mathrm{Kx}$, and $\mathrm{AG}$ based on $E$ were quite consistent, indicating superiority of the wheat cultivars TBIO Sinuelo and BRS Parrudo (RC> $1 ; \mathrm{Kx}>\mathrm{Ky}$ and $\mathrm{AG}>0$ ) when competing with tetraploid ryegrass (Table 3). For the other comparisons (TBIO Sinuelo x diploid ryegrass and BRS Parrudo x diploid ryegrass), no statistical differences were observed in at least two indices, as proposed by Bianchi et al. (2006).

\subsubsection{Growth-Related Traits}

The LA differed from the respective single control in all tested proportions, according to the Dunnett test $(\mathrm{p}<0.05)$ (Table 1). The CR, based on the LA, was quite consistent, indicating 
superiority of the species whenever they represented the majority in proportion, regardless of the wheat cultivar, and without differences between crop and weed when the densities were equivalent (Table 3). The same behavior was observed for AG based on LA. It is worth noting that the variable LA of the cultivar BRS Parrudo was higher than expected, especially when in the presence of diploid ryegrass (Figure 3), a fact that contributes to an increase in the photosynthetic rate and greater competitiveness.

The DM of wheat cultivars and competitors (Table 1) differed from the respective competition-free controls, according to the Dunnett test $(\mathrm{p}<0.05)$, for all levels of interaction between species. The higher the proportion of the competitor in association with the cultivars, the greater the damage to the crop variables (Table 1). The same tendency for DM reduction verified in the crop was observed in the diploid and tetraploid ryegrass (Table 1).

The CR showed a significant effect for the cultivar BRS Parrudo in coexistence with diploid and tetraploid ryegrass for the DM variable (Table 2). This indicates that ryegrass, both diploid and tetraploid, took advantage in the competition (Ky higher than $\mathrm{Kx}$ ), since values less than " 1 " were observed for the crop ( $\mathrm{t}>0.05)$. The CR for the cultivar TBIO Sinuelo did not have a significant effect; that is, diploid or tetraploid ryegrass did not affect DM of this cultivar. Changes in the competitive ability of wheat related to density and sowing time, as well as the cultivar selection, have been reported in the literature. However, competitiveness decreases when it is associated with high densities and early sowing (Andrew \& Storkey, 2017). The damage to the growth of crops and weeds when they are in competition in a given community has already been reported in other studies (Rigoli et al., 2008; Galon \& Agostinetto, 2009; Agostinetto et al., 2010; Galon et al., 2011).

The AG based on DM was greater for diploid and tetraploid ryegrass when living with the BRS Parrudo cultivar (Table 3). Similar results were found by Fontana et al. (2015), in which they identified that the barley presented greater interspecific competition and that weed caused losses in the accumulation of DM and LA. Thus, it becomes important for the sustainable cultivation systems (organic, agroecological, biodynamic, among others) to discover cultivars of the same crop that are more competitive when infested by a certain species of weed as an efficient management option to the detriment of chemical control (Andrew \& Storkey, 2017). 


\section{Ml Macrothink}

Journal of Agricultural Studies

ISSN 2166-0379

2020, Vol. 8, No. 3

Table 1. Differences between plants associated or not with the wheat cultivars TBIO Sinuelo and BRS Parrudo and of ryegrass biotypes for the morphological variables, stem diameter $(\mathrm{SD}, \mathrm{mm})$, leaf area $\left(\mathrm{LA}, \mathrm{cm}^{2} \mathrm{~m}^{-2}\right)$, number of tillers (NT) and shoot dry mass (DM, g) at 50 days after plant emergence

\begin{tabular}{|c|c|c|c|c|}
\hline Wheat:competitor & SD & LA & NT & DM \\
\hline Sinuelo:ryegrass(T) & \multicolumn{4}{|c|}{ Wheat Cultivar TBIO Sinuelo } \\
\hline $100: 00(\mathrm{C})$ & 2.65 & 49.95 & 4.45 & 20.89 \\
\hline $75: 25$ & 2.58 & 53.00 & 5.50 & $15.84 *$ \\
\hline $50: 50$ & 2.88 & $59.08 *$ & 3.85 & $9.63 *$ \\
\hline $25: 75$ & 2.41 & 49.91 & 4.62 & $10.32 *$ \\
\hline C.V $(\%)$ & 10.30 & 10.80 & 15.20 & 8.30 \\
\hline Sinuelo:ryegrass(T) & \multicolumn{4}{|c|}{ Competitor Ryegrass Tetraploid } \\
\hline $0: 100(\mathrm{C})$ & 1.86 & 43.61 & 91.0 & 20.59 \\
\hline $25: 75$ & 1.74 & 39.08 & $4.53^{*}$ & 19.73 \\
\hline $50: 50$ & 1.69 & 39.99 & $3.73^{*}$ & $9.77 *$ \\
\hline $75: 25$ & 1.79 & $32.88 *$ & $4.75 *$ & $11.15^{*}$ \\
\hline C.V (\%) & 15.50 & 10.60 & 13.40 & 10.60 \\
\hline Sinuelo:ryegrass(D) & \multicolumn{4}{|c|}{ Wheat Cultivar TBIO Sinuelo } \\
\hline $100: 00(\mathrm{C})$ & 2.50 & 57.22 & 5.62 & 24.73 \\
\hline $75: 25$ & 2.15 & 58.16 & $4.10^{*}$ & $17.14 *$ \\
\hline $50: 50$ & 2.31 & 56.95 & $3.75 *$ & $19.22 *$ \\
\hline $25: 75$ & 2.58 & 56.10 & $3.82 *$ & $2.14 *$ \\
\hline C.V (\%) & 16.00 & 11.30 & 13.70 & 11.60 \\
\hline Sinuelo:ryegrass(D) & \multicolumn{4}{|c|}{ Competitor Ryegrass Diploid } \\
\hline $0: 100(\mathrm{C})$ & 2.50 & 48.75 & 7.85 & 10.61 \\
\hline $25: 75$ & 2.15 & $40.66^{*}$ & $5.05 *$ & $9.55^{*}$ \\
\hline $50: 50$ & 2.31 & $38.99 *$ & $3.15^{*}$ & $8.90^{*}$ \\
\hline $75: 25$ & 2.58 & $28.99 *$ & $3.10 *$ & $2.25^{*}$ \\
\hline C.V $(\%)$ & 16.00 & 8.40 & 18.20 & 8.20 \\
\hline Parrudo:ryegrass $(\mathrm{T})$ & \multicolumn{4}{|c|}{ Wheat Cultivar BRS Parrudo } \\
\hline $100: 00(\mathrm{C})$ & 2.32 & 62.58 & 3.05 & 16.44 \\
\hline $75: 25$ & 2.23 & 58.33 & 2.80 & $9.77 *$ \\
\hline $50: 50$ & 2.33 & $81.57 *$ & 3.15 & $6.94 *$ \\
\hline $25: 75$ & 2.14 & 54.50 & 2.72 & $3.19 *$ \\
\hline C.V $(\%)$ & 7.70 & 10.70 & 16.70 & 12.30 \\
\hline Parrudo:ryegrass(T) & \multicolumn{4}{|c|}{ Competitor Ryegrass Tetraploid } \\
\hline $0: 100(\mathrm{C})$ & 2.08 & 45.05 & 7.20 & 17.75 \\
\hline $25: 75$ & $1.86^{*}$ & 39.55 & $4.42 *$ & 16.87 \\
\hline $50: 50$ & $1.54 *$ & 47.41 & $5.30 *$ & $12.95 *$ \\
\hline $75: 25$ & $1.73^{*}$ & 42.33 & $3.73^{*}$ & $10.52 *$ \\
\hline C.V $(\%)$ & 12.10 & 12.40 & 11.30 & 18.10 \\
\hline Parrudo:ryegrass(D) & \multicolumn{4}{|c|}{ Wheat Cultivar BRS Parrudo } \\
\hline $100: 00(\mathrm{C})$ & 3.55 & 53.62 & 2.88 & 19.61 \\
\hline $75: 25$ & 3.55 & 62.22 & 2.15 & $9.54 *$ \\
\hline $50: 50$ & 3.15 & $66.95 *$ & 2.98 & $9.45^{*}$ \\
\hline $25: 75$ & $4.08 *$ & $69.44 *$ & $3.95 *$ & $5.92 *$ \\
\hline C.V $(\%)$ & 8.70 & 10.50 & 14.50 & 10.30 \\
\hline Parrudo:ryegrass(D) & \multicolumn{4}{|c|}{ Competitor Ryegrass Diploid } \\
\hline $0: 100(\mathrm{C})$ & 2.33 & 34.66 & 4.72 & 18.80 \\
\hline $25: 75$ & 2.35 & $45.33^{*}$ & 5.15 & $11.00 *$ \\
\hline $50: 50$ & 1.91 & $41.44 *$ & 4.40 & $11.32 *$ \\
\hline $75: 25$ & 2.47 & 36.99 & 4.40 & $5.21 *$ \\
\hline C.V $(\%)$ & 13.90 & 10.90 & 8.60 & 8.30 \\
\hline
\end{tabular}

* Mean differs from the control (C) by the Dunnett test $(\mathrm{p} \leq 0.05)$. C.V., coefficient of variation. 
Table 2. Differences between plants associated or not with wheat cultivars TBIO Sinuelo and BRS Parrudo and of ryegrass biotypes for physiological variables, photosynthetic rate $(A$, $\mu$ mol m$\left.{ }^{-2} \mathrm{~s}^{-1}\right)$, internal $\mathrm{CO}_{2}$ concentration $\left(\mathrm{C}_{\mathrm{i}}, \mu \mathrm{mol} \mathrm{mol}^{-1}\right)$, carboxylation efficiency $(\mathrm{CE}$, mol $\mathrm{CO}_{2} \mathrm{~m}^{-2} \mathrm{~s}^{-1}$ ), transpiration $\left(E\right.$, mol $\mathrm{H}_{2} \mathrm{O} \mathrm{m}^{-2} \mathrm{~s}^{-1}$ ), water use efficiency (WUE, mol $\mathrm{CO}_{2} \mathrm{~mol}$ $\left.\mathrm{H}_{2} \mathrm{O}^{-1}\right)$ and stomatal conductance $\left(g_{\mathrm{S}}, \mathrm{mol} \mathrm{m}^{-2} \mathrm{~s}^{-1}\right)$ at 50 days after plant emergence

\begin{tabular}{|c|c|c|c|c|c|c|}
\hline Wheat:competitor & $\bar{A}$ & $\mathrm{C}_{\mathrm{i}}$ & $\mathrm{CE}$ & $E$ & EUA & gs \\
\hline Sinuelo:ryegrass(T) & \multicolumn{6}{|c|}{ Wheat Cultivar TBIO Sinuelo } \\
\hline $100: 00(\mathrm{C})$ & 44.36 & 260.50 & 0.17 & 7.82 & 5.68 & 0.78 \\
\hline $75: 25$ & 39.40 & $192.25 *$ & 0.21 & $9.81 *$ & $4.02 *$ & $1.54 \%$ \\
\hline $50: 50$ & 42.64 & $200.25 *$ & 0.22 & $11.00 *$ & $3.90 *$ & $2.46^{*}$ \\
\hline $25: 75$ & 42.28 & 220.50 & 0.19 & $10.39 *$ & $4.07 *$ & 1.66 \\
\hline C.V $(\%)$ & 8.00 & 16.00 & 16.30 & 6.60 & 9.80 & 22.80 \\
\hline Sinuelo:ryegrass(T) & \multicolumn{6}{|c|}{ Competitor Ryegrass Tetraploid } \\
\hline $0: 100(\mathrm{C})$ & 27.27 & 251.00 & 0.11 & 8.62 & 3.17 & 0.86 \\
\hline $25: 75$ & 20.18 & 278.50 & 0.07 & 8.38 & 2.41 & 0.80 \\
\hline $50: 50$ & 27.95 & 301.25 & 0.09 & $8.23^{*}$ & 3.43 & 0.71 \\
\hline $75: 25$ & 32.90 & 241.50 & 0.14 & $7.75^{*}$ & 4.25 & $0.52 *$ \\
\hline C.V $(\%)$ & 21.80 & 9.70 & 27.60 & 3.00 & 23.20 & 23.70 \\
\hline Sinuelo:ryegrass(D) & \multicolumn{6}{|c|}{ Wheat Cultivar TBIO Sinuelo } \\
\hline $100: 00(\mathrm{C})$ & 36.73 & 234.50 & 0.15 & 6.73 & 5.49 & 1.73 \\
\hline $75: 25$ & $53.02 *$ & 209.50 & $0.26^{*}$ & 6.24 & $8.45 *$ & $1.07 *$ \\
\hline $50: 50$ & 36.93 & 233.50 & 0.16 & 6.35 & 5.89 & 2.02 \\
\hline $25: 75$ & 45.75 & $166.50 *$ & $0.29 *$ & 6.98 & 6.59 & 1.38 \\
\hline C.V (\%) & 20.20 & 13.10 & 33.20 & 12.20 & 18.70 & 23.80 \\
\hline Sinuelo:ryegrass(D) & \multicolumn{6}{|c|}{ Competitor Ryegrass Diploid } \\
\hline $0: 100(\mathrm{C})$ & 26.88 & 215.25 & 0.13 & 6.13 & 4.39 & 0.72 \\
\hline $25: 75$ & 31.64 & 215.00 & 0.14 & $5.04 *$ & 6.44 & 0.66 \\
\hline $50: 50$ & 25.41 & 241.50 & 0.11 & $4.93^{*}$ & 5.21 & $0.50^{*}$ \\
\hline $75: 25$ & 20.68 & 274.25 & 0.08 & $4.38^{*}$ & 4.95 & $0.42 *$ \\
\hline C.V $(\%)$ & 28.60 & 7.70 & 35.50 & 13.80 & 35.50 & 14.70 \\
\hline Parrudo:ryegrass(T) & \multicolumn{6}{|c|}{ Wheat Cultivar BRS Parrudo } \\
\hline $100: 00(\mathrm{C})$ & 48.24 & 157.25 & 0.31 & 5.34 & 9.04 & 0.77 \\
\hline $75: 25$ & 56.49 & $220.00 *$ & 0.26 & 6.70 & 8.57 & 0.96 \\
\hline $50: 50$ & 53.64 & 153.50 & 0.38 & 6.48 & 8.54 & 1.29 \\
\hline $25: 75$ & $36.82 *$ & 208.25 & 0.18 & $6.84^{*}$ & $5.41 *$ & 1.18 \\
\hline C.V $(\%)$ & 12.60 & 20.50 & 34.1 & 14.30 & 20.70 & 34.60 \\
\hline Parrudo:ryegrass(T) & \multicolumn{6}{|c|}{ Competitor Ryegrass Tetraploid } \\
\hline $0: 100(\mathrm{C})$ & 43.03 & 212.00 & 0.20 & 5.11 & 8.49 & 0.95 \\
\hline $25: 75$ & $34.44 *$ & $175.50 *$ & 0.20 & 4.81 & 7.26 & $0.53 *$ \\
\hline $50: 50$ & $21.31 *$ & $272.00 *$ & $0.08^{*}$ & $3.81^{*}$ & $5.71 *$ & $0.60 *$ \\
\hline $75: 25$ & $21.96 *$ & $237.50 *$ & $0.09 *$ & $3.76^{*}$ & $5.84 *$ & 0.81 \\
\hline C.V $(\%)$ & 13.50 & 4.60 & 19.10 & 13.20 & 19.90 & 27.80 \\
\hline Parrudo:ryegrass(D) & \multicolumn{6}{|c|}{ Wheat Cultivar BRS Parrudo } \\
\hline $100: 00(\mathrm{C})$ & 35.87 & 224.25 & 0.16 & 4.94 & 1.06 & 1.06 \\
\hline $75: 25$ & 37.36 & 218.75 & 0.17 & 5.76 & 1.10 & 1.10 \\
\hline $50: 50$ & 45.14 & 204.50 & 0.22 & 6.56 & 1.65 & 1.65 \\
\hline $25: 75$ & $50.95 *$ & 204.00 & $0.26^{*}$ & $6.81^{*}$ & 1.86 & 1.86 \\
\hline C.V $(\%)$ & 16.00 & 12.20 & 30.70 & 18.90 & 46.80 & 46.80 \\
\hline Parrudo:ryegrass(D) & \multicolumn{6}{|c|}{ Competitor Ryegrass Diploid } \\
\hline $0: 100(\mathrm{C})$ & 28.32 & 254.50 & 0.11 & 4.93 & 0.84 & 0.84 \\
\hline $25: 75$ & 26.16 & 265.50 & 0.10 & 4.63 & 0.95 & 0.95 \\
\hline $50: 50$ & 30.39 & $207.50 *$ & 0.15 & 5.71 & $0.63 *$ & $0.63^{*}$ \\
\hline $75: 25$ & 33.99 & 232.50 & 0.15 & 5.93 & $0.60 *$ & $0.60 *$ \\
\hline C.V (\%) & 27.50 & 7.30 & 33.30 & 28.70 & 17.20 & 17.20 \\
\hline
\end{tabular}

* Mean differs from the control (C) by the Dunnett test $(\mathrm{p} \leq 0.05)$. C.V., coefficient of variation. 
Table 3. Competitiveness indexes between wheat cultivars TBIO Sinuelo and BRS Parrudo with tetraploid (T) and diploid (D) ryegrass biotypes, expressed by relative competitiveness $(\mathrm{RC})$, relative clustering (K) and aggressiveness (AG) coefficients, obtained in experiments conducted in substitute series, at 50 days after plant emergence

\begin{tabular}{|c|c|c|c|c|}
\hline Variable & $\mathrm{RC}$ & $\mathrm{K}_{\mathrm{X}}$ (wheat) & $\mathrm{K}_{\mathrm{Y}}$ (competitor) & $\mathrm{AG}$ \\
\hline & \multicolumn{4}{|c|}{ Stem diameter $(\mathrm{mm})$} \\
\hline TBIO Sinuelo x Ryegrass (T) & $1.207 \pm 0.086$ & $1.194 \pm 0.066^{*}$ & $0.854 \pm 0.099$ & $0.087 \pm 0.030$ \\
\hline TBIO Sinuelo x Ryegrass (D) & $1.453 \pm 0.104 *$ & $0.864 \pm 0.056^{*}$ & $0.482 \pm 0.058$ & $0.140 \pm 0.025^{*}$ \\
\hline BRS Parrudo x Ryegrass (T) & $1.372 \pm 0.046^{*}$ & $1.031 \pm 0.119^{*}$ & $0.596 \pm 0.077$ & $0.134 \pm 0.008 *$ \\
\hline \multirow[t]{2}{*}{ BRS Parrudo x Ryegrass (D) } & $1.112 \pm 0.128$ & $0.815 \pm 0.101$ & $0.717 \pm 0.12$ & $0.034 \pm 0.053$ \\
\hline & \multicolumn{4}{|c|}{ Number of tillers } \\
\hline TBIO Sinuelo x Ryegrass (T) & $2.136 \pm 0.225^{*}$ & $0.804 \pm 0.167^{*}$ & $0.259 \pm 0.029$ & $0.228 \pm 0.044^{*}$ \\
\hline TBIO Sinuelo x Ryegrass (D) & $1.698 \pm 0.184^{*}$ & $0.502 \pm 0.032 *$ & $0.252 \pm 0.021$ & $0.133 \pm 0.027^{*}$ \\
\hline BRS Parrudo x Ryegrass (T) & $1.403 \pm 0.067 *$ & $1.086 \pm 0.118^{*}$ & $0.582 \pm 0.000$ & $0.148 \pm 0.025^{*}$ \\
\hline \multirow{2}{*}{ BRS Parrudo x Ryegrass (D) } & $1.119 \pm 0.089$ & $1.089 \pm 0.106$ & $0.876 \pm 0.051$ & $0.052 \pm 0.038$ \\
\hline & \multicolumn{4}{|c|}{ Dry mass $\left(\mathrm{g} \mathrm{pot}^{-1}\right)$} \\
\hline TBIO Sinuelo x Ryegrass (T) & $0.995 \pm 0.102$ & $0.300 \pm 0.015$ & $0.313 \pm 0.031$ & $-0.007 \pm 0.023$ \\
\hline TBIO Sinuelo x Ryegrass (D) & $0.927 \pm 0.037$ & $0.638 \pm 0.038$ & $0.723 \pm 0.014$ & $-0.031 \pm 0.016$ \\
\hline BRS Parrudo x Ryegrass (T) & $0.607 \pm 0.088^{*}$ & $0.268 \pm 0.010$ & $0.595 \pm 0.108$ & $-0.154 \pm 0.045^{*}$ \\
\hline \multirow[t]{2}{*}{ BRS Parrudo x Ryegrass (D) } & $0.801 \pm 0.045^{*}$ & $0.318 \pm 0.021^{*}$ & $0.431 \pm 0.009$ & $-0.060 \pm 0.014^{*}$ \\
\hline & \multicolumn{4}{|c|}{ Photosynthetic rate $\left(\mu \mathrm{mol} \mathrm{m}{ }^{-2} \mathrm{~s}^{-1}\right)$} \\
\hline TBIO Sinuelo x Ryegrass (T) & $0.984 \pm 0.160$ & $0.942 \pm 0.102$ & $1.108 \pm 0.19$ & $-0.032 \pm 0.074$ \\
\hline TBIO Sinuelo x Ryegrass (D) & $1.139 \pm 0.260$ & $1.091 \pm 0.253$ & $0.952 \pm 0.187$ & $0.030 \pm 0.093$ \\
\hline BRS Parrudo x Ryegrass (T) & $2.251 \pm 0.240 *$ & $1.362 \pm 0.306^{*}$ & $0.329 \pm 0.007$ & $0.308 \pm 0.056^{*}$ \\
\hline \multirow[t]{2}{*}{ BRS Parrudo x Ryegrass (D) } & $1.231 \pm 0.180$ & $1.773 \pm 0.286$ & $1.266 \pm 0.266$ & $0.093 \pm 0.064$ \\
\hline & \multicolumn{4}{|c|}{ Internal $\mathrm{CO}_{2}$ concentration $\left(\mu \mathrm{mol} \mathrm{mol}{ }^{-1}\right)$} \\
\hline TBIO Sinuelo x Ryegrass (T) & $0.641 \pm 0.046^{*}$ & $0.632 \pm 0.065^{*}$ & $1.503 \pm 0.049$ & $-0.216 \pm 0.028^{*}$ \\
\hline TBIO Sinuelo x Ryegrass (D) & $0.890 \pm 0.038$ & $0.996 \pm 0.057 *$ & $1.283 \pm 0.064$ & $-0.063 \pm 0.023$ \\
\hline BRS Parrudo x Ryegrass (T) & $0.076 \pm 0.096$ & $1.068 \pm 0.313$ & $1.790 \pm 0.02$ & $-0.153 \pm 0.061$ \\
\hline \multirow[t]{2}{*}{ BRS Parrudo X Ryegrass (D) } & $1.119 \pm 0.056$ & $0.847 \pm 0.076$ & $0.688 \pm 0.004$ & $0.048 \pm 0.023$ \\
\hline & \multicolumn{4}{|c|}{ Carboxylation efficiency $\left(\mathrm{mol} \mathrm{CO} \mathrm{CO}_{2}^{-2} \mathrm{~s}^{-1}\right)$} \\
\hline TBIO Sinuelo x Ryegras & $1.509 \pm 0.174$ & $1.754 \pm 0.403$ & $0.742 \pm 0.108$ & $0.197 \pm 0.061^{*}$ \\
\hline TBIO Sinuel & $1.458 \pm 0.414$ & $1.478 \pm 0.538$ & $0.757 \pm 0.155$ & $0.133 \pm 0.114$ \\
\hline BRS Parrudo X Ryegrass (T) & $3.151 \pm 0.664 *$ & $3.390 \pm 2.232$ & $0.239 \pm 0.005$ & $0.413 \pm 0.124 *$ \\
\hline \multirow[t]{2}{*}{ BRS Parrudo X Ryegrass (D) } & $.139 \pm 0.182$ & $3.286 \pm 1.531$ & $2.142 \pm 0.548$ & $0.054 \pm 0.093$ \\
\hline & \multicolumn{4}{|c|}{ Leaf area $\left(\mathrm{cm}^{2}\right.$ pot $\left.^{-1}\right)$} \\
\hline TBIO Sinuelo x Ryegrass (T) & $1.29 \pm 0.041^{*}$ & $1.463 \pm 0.119^{*}$ & $0.848 \pm 0.025$ & $0.133 \pm 0.010^{*}$ \\
\hline TBIO Sinuelo x Ryegras & $1.254 \pm 0.099$ & $1.008 \pm 0.111^{*}$ & $0.670 \pm 0.047$ & $0.098 \pm 0.037$ \\
\hline BRS Parrudo x Ryegrass (T) & $1.247 \pm 0.084$ & $1.910 \pm 0.196^{*}$ & $1.123 \pm 0.095$ & $0.126 \pm 0.037 *$ \\
\hline \multirow[t]{2}{*}{ BRS Parrudo x Ryegrass (D) } & $1.044 \pm 0.025$ & $1.682 \pm 0.139$ & $1.492 \pm 0.068$ & $0.027 \pm 0.015$ \\
\hline & \multicolumn{4}{|c|}{ Transpiration $\left(\mathrm{mol} \mathrm{H}_{2} \mathrm{O} \mathrm{m}^{-2} \mathrm{~s}^{-1}\right)$} \\
\hline TBIO Sinuelo x Ryegrass (T) & $1.477 \pm 0.083^{*}$ & $2.446 \pm 0.319^{*}$ & $0.917 \pm 0.044$ & $0.225 \pm 0.034^{*}$ \\
\hline TBIO Sinuelo x Ryegrass (D) & $1.170 \pm 0.054^{*}$ & $0.930 \pm 0.164$ & $0.678 \pm 0.06$ & $0.070 \pm 0.024$ \\
\hline BRS Parrudo x Ryegrass (T) & $1.634 \pm 0.098^{*}$ & $1.657 \pm 0.305^{*}$ & $0.607 \pm 0.087$ & $0.234 \pm 0.034 *$ \\
\hline \multirow[t]{2}{*}{ BRS Parrudo x Ryegrass (D) } & $1.018 \pm 0.021$ & $0.905 \pm 0.088$ & $0.871 \pm 0.07$ & $0.009 \pm 0.011$ \\
\hline & \multicolumn{4}{|c|}{ Water use efficiency $\left(\mathrm{mol} \mathrm{CO}_{2} \mathrm{~mol} \mathrm{H}_{2} \mathrm{O}^{-1}\right)$} \\
\hline TBIO Sinuelo x Ryegras & $0.682 \pm 0.137$ & $0.529 \pm 0.062$ & $1.289 \pm 0.276$ & $-0.198 \pm 0.086$ \\
\hline TBIO Sinuelo x Ryegrass (D) & $0.984 \pm 0.245$ & $1.275 \pm 0.314$ & $1.791 \pm 0.596$ & $-0.058 \pm 0.116$ \\
\hline BRS Parrudo x Ryegrass (T) & $1.384 \pm 0.106^{*}$ & $0.996 \pm 0.252$ & $0.514 \pm 0.06$ & $0.137 \pm 0.044^{*}$ \\
\hline \multirow[t]{2}{*}{ BRS Parrudo x Ryegrass (D) } & $1.204 \pm 0.18$ & $2.084 \pm 0.34$ & $1.508 \pm 0.3$ & $0.085 \pm 0.073$ \\
\hline & \multicolumn{4}{|c|}{ Stomatal conductance $\left(\mathrm{mol} \mathrm{CO} \mathrm{m}^{-2} \mathrm{~s}^{-1}\right)$} \\
\hline TBIO Sinuelo x Ryegrass (T) & $4.267 \pm 0.997 *$ & $-3.694 \pm 1.229 *$ & $0.751 \pm 0.178$ & $1.172 \pm 0.221^{*}$ \\
\hline TBIO Sinuelo x Ryegrass (D) & $1.848 \pm 0.470$ & $1.729 \pm 0.619$ & $0.544 \pm 0.096$ & $0.241 \pm 0.107$ \\
\hline BRS Parrudo x Ryegrass (T) & $2.674 \pm 0.314^{*}$ & $-2.274 \pm 8.516$ & $0.46 \pm 0.014$ & $0.523 \pm 0.093^{*}$ \\
\hline BRS Parrudo x Ryegrass (D) & $2.037 \pm 0.218^{*}$ & $-0.541 \pm 3.049$ & $0.619 \pm 0.096$ & $0.400 \pm 0.107^{*}$ \\
\hline
\end{tabular}

* Significant difference by the " $t$ " test $(\mathrm{p} \leq 0.05)$. Means \pm SEM. 
Various studies have also shown differences in terms of competitive ability between related species, such as, for example, between rice and rice grass (Agostinetto et al., 2008; Galon \& Agostinetto, 2009), barley and ryegrass (Galon et al., 2011), wheat and Alopecurus myosuroides (Andrew \& Storkey, 2017), and between soybeans versus common blackjack and wild poinsettia (Forte et al., 2017).

The SD and NT values of the cultivars TBIO Sinuelo and BRS Parrudo were the same as their competition-free controls (Table 1). In relation to the competitors, the diploid ryegrass in the presence of the cultivar TBIO Sinuelo showed lower NT; in the presence of BRS Parrudo, it showed lower values of NT and SD. Diploid ryegrass only showed a significant effect of competition with lower NT compared to its control in the presence of the cultivar TBIO Sinuelo. For the competitors, interspecific competition was more harmful than intraspecific competition.

The results demonstrate that the $\mathrm{RC}, \mathrm{Kx}$, and $\mathrm{AG}$ were higher for wheat when TBIO Sinuelo competed with diploid and tetraploid ryegrass and for NT and SD only for diploid ryegrass (Table 3). The cultivar BRS Parrudo showed higher values of RC, Kx, and AG in the presence of tetraploid ryegrass.

Studies show that normally the crop has greater competitive potential in relation to weed species, since competition between individuals of the same species (intraspecific) is generally greater than competition between individuals of different species (interspecific) (Vilá et al., 2004). It is also noteworthy that plants of the same species explore basically the same ecological niche, competing for the same resources in time and/or space (Rigoli et al., 2008; Moraes et al., 2009).

\section{Conclusion}

Based on PRs and TRPs, we can conclude that there is equivalence in the competition mechanisms and in the demand for environmental resources between diploid and tetraploid wheat and ryegrass.

Considering the absence of differences in $\mathrm{RC}, \mathrm{Kx} / \mathrm{Ky}$, and $A$ in the competitive ability of the wheat cultivars TBIO Sinuelo and BRS Parrudo with diploid and tetraploid ryegrass, it is possible to observe that there is equivalence in the competitive ability between species. Thus, we found that the two wheat cultivars and the diploid and tetraploid ryegrass are very similar in their ability to compete for environmental resources. However, diploid ryegrass showed a slight superiority to tetraploid ryegrass in terms of its ability to compete with wheat cultivars, with greater impacts on the variables analyzed.

\section{References}

Agostinetto, D., \& Vargas, L. (2014). Weed resistance to herbicides in Brazil. [Resistência de plantas daninhas a herbicidas no Brasil]. Pelotas: UFPel, 398 p. [In Portuguese]

Agostinetto, D. et al. (2008). Critical period for weed competition with wheat. Planta Daninha, 26, 271-278. https://doi.org/10.1590/S0100-83582008000200003 
Agostinetto, D. et al (2010). Interference and economic weed threshold (Ewt) of barnyardgrass on rice as a function of crop plant arrangement. Planta Daninha, 28, 993-1003. https://doi.org/10.1590/S0100-83582010000500007

Agostinetto, D. et al. (2013). Relative competitive ability of crabgrass in coexistence with flooded rice and soybean. Pesquisa Agropecuária. Brasileira, 48, 1315-1322. https://doi.org/10.1590/S0100-204X2013001000002.

Agostinetto, D. et al. (2017). Competition between wheat and ryegrass under different levels of nitrogen fertilization. Planta daninha, 35, e017165037. https://doi.org/10.1590/s0100-83582017350100050

Almeida, M. L., \& Mundstock, C. M. (2001). Light quality affects tillering on wheat when grown under competition. Ciência Rural, 31, 401-408.

https://doi.org/10.1590/S0103-84782001000300006

Aminpanah, H., \& Javadi, M. (2011). Competitive ability of two rice cultivars (Oryza sativa L.) with barnyardgrass (Echinochloa crusgalli (L.) p. beauv.) in a replacement series study. Advances in Environmental Biology, 5, 2669-2675.

Andrew, I. K. S., \& Storkey, J. (2017). Using simulation models to investigate the cumulative effects of sowing rate, sowing date and cultivar choice on weed competition. Crop Protection, 95, 109-115. https://doi.org/10.1016/j.cropro.2016.05.002

Baker, N. R., \& Rosenqvst, E. (2004). Applications of chlorophyll fluorescence can improve crop production strategies: an examination of future possibilities. Journal of Experimental Botany, 55, 1607-1621. https://doi.org/10.1093/jxb/erh196

Ballaré, C. L. et al. (1987). Early detection of neighbour plants by phytochrome perception of spectral changes in reflected sunlight. Plant, Cell \& Environment, 10, 551-557. https://doi.org/10.1111/1365-3040.ep11604091

Balocchi, O. A., \& López, I. L. (2009). Herbage production, nutritive value and grazing preference of diploid and tetraploid perennial ryegrass cultivars (Lolium perenne L.). Chilean $\begin{array}{lllll}\text { Journal of Agricultural } & \text { Research, } & \text { 331-339. }\end{array}$ https://doi.org/10.4067/S0718-58392009000300005

Bianchi, M. A., Fleck, N. G., \& Lamego, F. P. (2006). Proportion among soybean and competitor plants and the relations of mutual interference. Ciência Rural, 36, 1380-1387. https://doi.org/10.1590/S0103-84782006000500006

Bustamante, F. O. et al. (2015). Analysis of nuclear DNA content and chromosome number for screening genotypes and crosses in Annual Ryegrass (Lolium multiflorum Lam.). Australian Journal of Crop Science, 9, 666-670.

Carvalho, S. J. P., \& Christoffoleti, P. J. (2008). Competition of Amaranthus species with dry $\begin{array}{lllll}\text { bean } & \text { plants. } & \text { Scientia } & \text { Agricola, } & \text { 65, }\end{array}$ https://doi.org/10.1590/S0103-90162008000300003

Concenço, G., \& Galon, L. (2014) Script for analysis of competition experiments by the 
substitutive method in the "R". [Script para análises de experimentos de competição pelo método substitutivo no "R"]. Dourados: EMBRAPA, 24 p. Available: https://ainfo.cnptia.embrapa.br/digital/bitstream/item/114713/1/DOC2014124-com-Anexos.p df. (21 April 2020) [In Portuguese]

Confortin, A. C. C. et al. (2013). Different herbage masses on morphogenetic and structural traits of Italian ryegrass. Ciência Rural, 43, 496-502. https://doi.org/10.1590/S0103-84782013005000003

Côrrea, M. J. P. et al. (2015). Periods of weed interference in cowpea. Revista de Ciências Agroambientais, 13, 50-56. [In Portuguese]

Costa, O. A. D. et al. (2018). Yield, structural composition and nutritive characteristics of ryegrass cultivars used to haymaking in lowland soils. Bioscience Journal, 34, 1232-1238. https://doi.org/10.14393/BJ-v34n5a2018-39405

Cousens, R. (1991). Aspects of the design and interpretation of competition (interference) experiments. Weed Technology, 5, 664-673. https://doi.org/10.1017/S0890037X00027524

Cousens, R., \& O’Neill, M., (1993). Density dependence of replacement series experiments. Oikos, 66, 347-352. https://doi.org/10.2307/3544824

Délye, C., Jasieniuk, M., \& Le Corre, V. (2013). Deciphering the evolution of herbicide resistance in weeds. Trends in Genetics, 29, 649-658. https://doi.org/10.1016/j.tig.2013.06.001

EMBRAPA (2013). Brazilian system of soil classification [Sistema brasileiro de classificação de solos]. (1st ed.). Brasília: Embrapa Solos. P. 154 p. [In Portuguese]

FAO (2020). Crop Prospects and Food Situation - Quarterly Global Report No. 1. Rome: Food and Agriculture Organization of United Nations. p. 46. https://doi.org/10.4060/ca8032en

Ferreira, E. A. et al. (2008). Glyphosate distribution and nutrient accumulation in ryegrass biotypes. Planta Daninha, 26, 165-173. https://doi.org/10.1590/S0100-83582008000100017

Fontana, L. C. et al. (2015). Barley competitive ability in coexistence with black oat or wild radish. Cientifica, 43, 22-29. https:// doi.org/10.15361/1984-5529.2015v43n1p22-29

Fontaneli, R. S. et al. (2012). Annual winter forage grasses. [Gramíneas forrageiras anuais de inverno]. In R.S. Fontaneli, H.P. Santos, \& R.S. Fontaneli (Eds). Forrageiras para integração lavoura-pecuária-floresta na região sul-brasileira. (2nd ed.) (pp. 127-172). Brasília: EMBRAPA. [In Portuguese]

Forte, C. T. et al. (2017). Competitive ability of transgenic soybean cultivars coexisting with weeds. Agrária, 12, 185-193. https:// doi.org/10.5039/agraria.v12i2a5444

Forte, C. T. (2018). Soil management systems and their effect on the weed seed bank. Pesquisa Agropecuária Brasileira, 53, 435-442. https://doi.org/10.1590/s0100-204x2018000400005 
Galon, L., \& Agostinetto, D. (2009). Comparison of empirical models for predicting yield loss of irrigated rice (Oryza sativa) mixed with Echinochloa spp. Crop Protection, 28, 825-830. https://doi.org/10.1016/j.cropro.2009.06.005

Galon, L. et al. (2011). Competitive ability of barley cultivars against ryegrass. Planta Daninha, 29, 771-781. https://doi.org/10.1590/S0100-83582011000400007

Galon, L. et al. (2015). Competitive ability of canola hybrids with weeds. Planta Daninha, 33, 413-423. https://doi.org/10.1590/S0100-83582015000300004

Galon, L. et al. (2017). Competitive relative ability of barley cultivars in interaction with turnip. Planta Daninha, 35, e017164016. https://doi.org/10.1590/s0100-83582017350100012

Galon, L. et al. (2019). Weed interference period and economic threshold level of ryegrass in wheat. Bragantia, 78, 409-422. https://doi.org/10.1590/1678-4499.20180426

Gest, H. (2002). History of the word photosynthesis and evolution of its definition. Photosynthesis Research, 73, 7-10. https://doi.org/10.1023/A:1020419417954

Gherekhloo, J. et al. (2010). Multispecies weed competition and their economic threshold on the wheat crop. Planta Daninha, 28, 239-246. https://doi.org/10.1590/S0100-83582010000200002

Henckes, J. R. et al. (2019). Fitness cost and competitive ability of ryegrass susceptible and with multiple resistance to glyphosate, iodosulfuron-methyl, and pyroxsulam. Planta Daninha, 37, e019197532. https://doi.org/10.1590/s0100-83582019370100091

Hoffman, M. L., \& Buhler, D. D. (2002). Utilizing Sorghum as a functional model of crop weed competition. Weed Science, 50, 466-472. https://doi.org/10.1614/0043-1745(2002)050[0473:USAAFM]2.0.CO;2

Hussain, M. et al. (2017). Influence of priming on emergence, weed infestation, growth and yield of wheat sown under different tillage practices. International Journal of Agriculture and Biology, 19, 367-373. https://doi.org/10.17957/IJAB/15.0188

Kaundun, S. et al. (2013). Role of a novel I1781T mutation and other mechanisms in conferring resistance to acetyl-CoA carboxylase inhibiting herbicides in a black grass population. PloS ONE, 8, e69568. https://doi.org/10.1371/journal.pone.0069568

Lamego, F. P. et al. (2013). Competitive ability of wheat cultivars against weeds. Planta Daninha, 31, 521-531. https://doi.org/10.1590/S0100-83582013000300004

Mahmood K. et al. (2016). Multiple herbicide resistance in Lolium multiflorum and identification of conserved regulatory elements of herbicide resistance genes. Frontiers in Plant Science, 7, 160. https://doi.org/10.3389/fpls.2016.01160

Mariani, F. et al. (2016). Inheritance of resistance of Lolium multiflorum to iodosulfuron-methyl sodium. Planta Daninha, 33, 351-356. https://doi.org/10.1590/0100-83582015000200021 
Moraes, P. V. D. et al. (2009). Relative competitiveness of soybean against red-rice. Planta Daninha, 27, 35-40. https://doi.org/10.1590/S0100-83582009000100006

Nair, R. (2004). Developing tetraploid perennial ryegrass (Lolium perenne L.) populations. New Zealand Journal of Agricultural Research, 47, 45-49. https://doi.org/10.1080/00288233.2004.9513569

Oliveira, C. et al. (2014). Does the resistance to glyphosate herbicide affect the competitive ability of ryegrass with soybean? Planta Daninha, 32, 189-196. https://doi.org/10.1590/S0100-83582014000100021

Pereira, R. C. et al. (2012). Chromosome doubling of grasses: an alternative to plant breeding. Ciência Rural, 42, 1278-1285. https://doi.org/10.1590/S0103-84782012000700023

Pereira, R. C. et al. (2014). Chromosome duplication in Lolium multiflorum Lam. Crop Breeding and Biotechnology, 14, 251-255. https://doi.org/10.1590/1984-70332014v14n4n39

Pereira, R. C. et al. (2017) Stability in chromosome number and DNA content in synthetic tetraploids of Lolium multiflorum after two generations of selection. Ciência Rural, 47, e20150767. https://doi.org/10.1590/0103-8478cr20150767

Rigoli, R. P. et al. (2008). Relative competitive ability of wheat (Triticum aestivum) intercropped with Italian ryegrass (Lolium multiflorum) or wild radish (Raphanus raphanistrum). Planta Daninha, $26, \quad$ 93-100. https://doi.org/10.1590/S0100-83582008000100010

ROLAS (2016). Fertilization and liming manual for the states of Rio Grande do Sul and Santa Catarina. [Manual de adubação e calagem para os estados do Rio Grande do Sul e Santa Catarina]. (10th ed.). Porto Alegre: Sociedade Brasileira de Ciência do Solo. p. 376. [In Portuguese]

Roush, M. L. et al. (1989). A comparison of methods for measuring effects of density and proportion in plant competition experiments. Weed Science, 37, 268-275. https://doi.org/10.1017/S0043174500071897

Smith, K. F. et al. (2003). The effects of ploidy and seed mass on the emergence and early vigour of perennial ryegrass (Lolium perenne L.) cultivars. Australian Journal of Experimental Agriculture, 43, 481-486. https://doi.org/10.1071/EA01130

Stivanin, S. C. B. et al. (2014). Ingestive behavior of hoggets given different types of supplement on ryegrass pasture. Acta Scientiarum. Animal Sciences, 36, 101-107. https://doi.org/10.4025/actascianimsci.v36i1.21641

Szareski V. J. et al. (2019). Genetic and phenotypic multi-character approach applied to multivariate models for wheat industrial quality analysis. Genetics and Molecular Research, 18, GMR18223. https://doi.org/10.4238/gmr18223

Taiz, L. et al. (2014). Plant Physiology and Development. (6th ed.). Sunderland: Sinauer 
Associates. p. 896.

Tironi, S. P. et al. (2014). Time of emergency of ryegrass and wild radish on the competitive ability of barley crop. Ciência Rural, 44, 1527-1533. https://doi.org/10.1590/0103-8478cr20131633

Vargas, L. et al. (2005). Change in the biological characteristics of ryegrass (Lolium multiflorum) biotypes caused by resistance to the herbicide glyphosate. Planta Daninha, 23, 153-160. https://doi.org/10.1590/S0100-83582005000100018

Vian, A. L. et al. (2016). Spatial variability of grain yield of irrigated corn and its correlation with explanatory plant variables. Ciência Rural, 46, 464-471. https://doi.org/10.1590/0103-8478cr20150539

Vilá, M., Williamson, M., \& Lonsdale, M. (2004). Competition experiments on alien weeds with crops: lessons for measuring plant invasion impact. Biological Invasions, 6, 59-69. https://doi.org/10.1023/B:BINV.0000010122.77024.8a

Walker, G. K., Blackshaw, R. E., \& Dekker, J. (1988). Leaf area and competition for light between plant species using direct sunlight transmission. Weed Technology, 2, 159-165. https://doi.org/10.1017/S0890037X00030311

Wanic, M. et al. (2013). Competition between spring barley (Hordeum vulgare L.) and italian ryegrass (Lolium multiflorum Lam.) under different water supply conditions. Acta Agrobotanica, 66, 73-80. https://doi.org/10.5586/aa.2013.040

\section{Copyright Disclaimer}

Copyright for this article is retained by the author(s), with first publication rights granted to the journal.

This is an open-access article distributed under the terms and conditions of the Creative Commons Attribution license (http://creativecommons.org/licenses/by/4.0/). 